\title{
法務省旧本館の木構造技術に関する研究 \\ A STUDY OF THE WOODEN FRAME OF THE OLD BUILDING OF THE MINISTRY OF JUSTICE
}

\author{
堀内正昭* \\ Masaaki HORIUCHI
}

\begin{abstract}
The old building was designed by Ende \& Böckmann. The construction began in 1888 and was completed in 1895. It had a floor frame and a roof frame in a style known at that time as 'German construction'. The beams of the single flooring were ca. 7 meters in length and were placed every ca. 90 centimeters. They were reinforced by intertruss bracings and filled with cinder for soundproofing, as was often done in Berlin. The roof frame was similar to roof frames in Germany, but in Germany there were no examples where posts of the roof were reinforced by braces on either side using many diagonal posts. The reason may be because attic space was unnecessary in Japan and the roof frame was designed to strengthen the frame after the Nobi Earthquake of 1891.
\end{abstract}

\section{Keywords:Roof frame, Floor frame, Intertruss bracing, Soundproofing, Nobi Earthquake, The Old Building of the Ministry of Justice 小屋組，床組，振れ止め，響き止め，濃尾地震，法務省旧本館}

はじめに

筆者は、法務省旧㷊館（汨司法督庁舎、1888～1895年）の創建時 の構法を明らかにするという目的をもって、これまでに碇睽鉄構法 の位㯰づけを行うとともに ${ }^{2)}$ 、とくに 3 階床構法の復原を武みた ${ }^{3)}$ 。 本稿はその続編であり、床組ならびに小屋組を取り上げる。これら の構法に関して法務省旧本館の建築仕様書には、次の記述がある。

「床梁及木屋組（＝小屋組のこと、筆者註）等スベテ独乙法ナリ トス 床八震動 防グ為メ 梁間へ筋違木 止ノ為入石炭焚売 $\exists$ 充填入」4)

同建築仕様書では、床に振れ止めと響き止めの技法が使われ、そ れが小屋組を含めてドイツ式であったという。このうちドイツ式の 小屋組については、明治期の建築学の文献では「ドイツ小屋」と紹 介されて、他の小屋組と区別されていた。

そこで、本稿では、振れ止め・響き止めをもつ床組ならびに小屋 組が具体的にどのような構法であったのかを日本とドイツの文献か ら明らかにし、法務省旧本館の創建時の木構造技術の位置づけを行 っていく。な拉、振れ止めは、床組と小屋組に用いられる補剛材で あるが、本稿で振れ止めというときはすべて床組のものを指す。ま た、旧本館の創建時の木造床と小屋組は、第二次世界大戦と戦後の 復旧工事によって現存しないので、㓣建時の図面を分析対象にする。
I 。振れ止め・響き止めについて

(i ) 明治期の建築学の文献

a) 『建築学階梯』5)

本書の中巻第 5 編木材論及大工職の「根太」の項には、振れ止め、 響き止めが図解されるとともに（図 1)、次の記述がある。まず振 れ止めについて、「根太の張間 10 尺以上のときは所謂触止なるも のを其間に取付くべし。触止とは幅 1 寸 5 分乃至 2 寸 5 分厚さ 8 分 程の小材にて (略) 根太間に交叉して釘付にしたるものなり」

次に響き止めについては、「根太間に疎柔なる物を散布し以て音 響或は臭気の伝達を防ぐ事あり。特に単材床に在ては最も必要なり とす」と書かれ、根太間には栈で支えられた受板を配し、その上 に置かれる「詰物はモルタル中に稿を混ぜたるもの又はモルタル土 及び鍛冶場の灰の調合物等なり。」

\section{b) 『建築学講義録』6)}

本畫の第 2 巻 第 10 節「床」には、「振動止」と「音響止」の 項があり、図（図2）が揭載される。

まず振れ止めについて、「根太が 10 尺より長き時は、横振のせ ざるため、7尺位に振動止を設け置くべし、振動止は其実唯横振を 防ぐばかりでなく、根太より根太へ荷が伝いて相持になるゆえ、床 が余程丈夫になるものと知るべし、（略）根太と根太との間へ厚八

本論文は, 日本建築学会関東支部研究報告葉で発表した内容に新たな知見を加えたものである゙。
* 昭和女子大学短期大学:部生活文化学科 助教授・エ博 $\quad$ Assoc. Prof., Dept. of Domestic Science, Showa Women's University, Dr. Eng. 
分位見付一寸五分位より二寸五分位までの木を打遧に钉付にしたる もの」

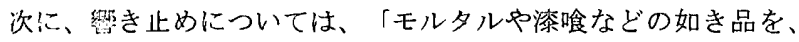
根太と根太の間へ張りたる荒床の上に影きて、音蠁を止める仕方」 上記述され、詰物には、石灰モルタルに土と石炭䃾などを混ぜたも の、フェルト、稿莚などが上げられる。

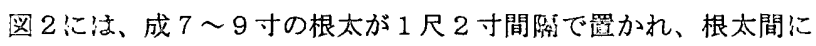
は、振れ止め、栈で支えられた受板、そして詰物が表示されている。 c) 『和洋改良大建築学』7)

本落の第 7 章屋内ノ㯜造 第 57 節「床」の項に注、振れ止めに 閶して次の説明がある。

「振止床八単床ノ一種ニシテ住家ニ多ク用ヒラレ 張間 10 尺以 上ノ時 根太間二成 3 寸㢯至 1 寸 5 分幅 1 寸位ノ木片ニテ造レル振 止 其ママ筋堂ニナシ 根太人大釷打卜為ス方法」

この記述に絗いて、本㸷にはドイツの床組が紹介され、3 種類の 振れ止めが図示され（図３）、次の説明がつく。

独冕流ニテ八根太习廃シ 成 1 尺以上幅 5 寸以上ノ梁习真々 3 尺位二架渡シ 梁ノ横面二小孔习彫り 振止八 2 寸 5 分角位ノモノ 7図ノ如ク筋逢二欠込ミ 4、5 尺間二取付々 或八卓1尺以上ノ 顿 $\exists$ 小孔嵌込ミ 或八振止板受二板 7 载七目板 $习$ 打于（咯）」

以上の文献から、振れ止めは、根太の長さが 3 メートル以上の単

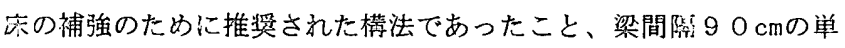
床で、振れ止めが成 $30 \mathrm{c} \mathrm{m} \times$ 幅 $15 \mathrm{~cm}$ 以上の梁に用いられたと きにドイツ式といったこと8)、そして、響き止めには、モルタルや 蒸哈に稿、石炭殼などを混ぜた詰物を用いていたことがすかる。

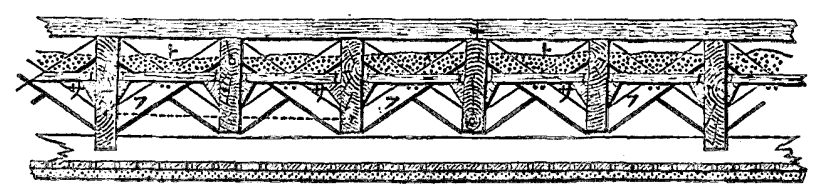

図 1 振れ止め。響き止め（『建築学階梯』）

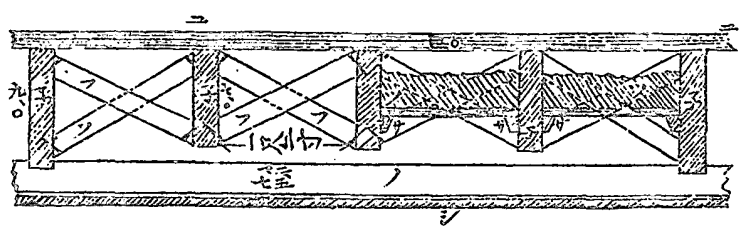

図 2 振れ止め。響き止め(『建築学講義録』)
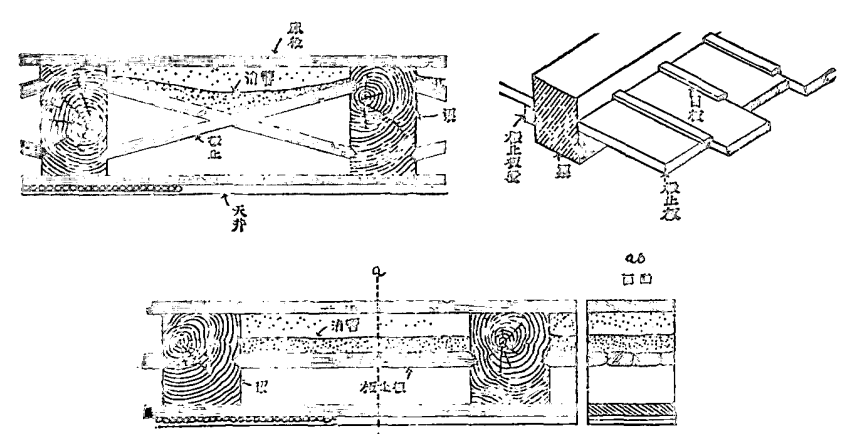

図 3 振れ止め。響き止め(『和洋改良大建築学』)
( i i ) ドイツの木橉造学の文献

19 世紀から 20 世紀の世紀転換期のドイツにおける木權造の文 献調查から、複数の文献に振れ止め・響き止めが紹介されていた。 以下、その概要を記してみる。

a ) 'Die Bau-und Kunstzimmerei'『大工と細工仕事』9)(図 4)

振れ止めは、本腾の「床組」の項に 5 種類の床組のうちの一例と して上げられ、「十字止め」Kreuzstickungと名づけられていた。 それは「幅の狭く成の大きな梁においてのみ推奨され、梁は十字を な寸机の突っ張りによって、優れた補強を得る。その際、十字止め の側圧に対処寸るために、両端から二つあるいは三つ目の梁までア ンカーによって結合される。j

b) 'Die Konstruktionen in Holz'『木構造』10) (図 5)

本排の「梁構造」の項に、「北アメリカ、イギリス、そして最近 ではドイッの諸都市において、木材の節約のためと、木の曲げに対 する強さを極力活用するために、しばしばいわゆる度板が忍用され た。しかし、この度板はたやすく反ったりするので、厚板は十字に 組まれた木によって互いに支えられなければならない。」

そして厚板による根太間隔は、36〜48 c mで、振れ止めによ って離れないようにアンカーで固定寸る必要があると渐れている。 c) 'Der Zimmermann'『大工』11) (図6)

本郝の「階上床」の項には、梁間隔 5 ○〜 $55 \mathrm{~cm}$ で、二つ割の 梁の長さが $6 \mathrm{~m}$ を越えるとき、振れ止めによる梁どうしの支え合い が推梁されること、両端の梁は側圧に抵抗できるように、壁と接す る面に扔いて角がとられ、㸷状に整形された石(A)が添えられるこ と、また、アンカー(B)による固定が望まれることが做かれ、振れ 止めの上には、稿土を置き、詰物で充填するという説明がある。

d) 'Die Holzkonstruktionen'『木棒造』12) (図 7)

本游の「梁權造」の項に、振れ止めについては、一点化集中する 荷重を梁全体に一様に分散させるという目的を持つこと、梁の長さ が 6 m以上のときに、とくに幅の狭い梁において推奨されること、 梁の間に約 2 m間隑で組まれることが㶳かれるとともに、梁の上あ るい仗澿の中に棟鉄製のアンカーを通すという説明がある。

以上のドイツの文献から、梁が $6 \mathrm{~m}$ 以上の長さで、成の大きさに 対して幅の小さな澿二厚顺を用いる場合に、振れ止めが求められ、 アンカーによる補強が推琶されたこと、そして、㗽き止めには、稿 土と詰物が使われたことがわかる。詰物には焼成土、高炉滓などが 用いられた13)

なお、本文中の図 3 と図 4 は同じと見なせるので、三橋四郎渚 『和洋改良大建筑学』の参考文献のひとつが’Die Bau-und Kunstzimmerei'であったといえる。

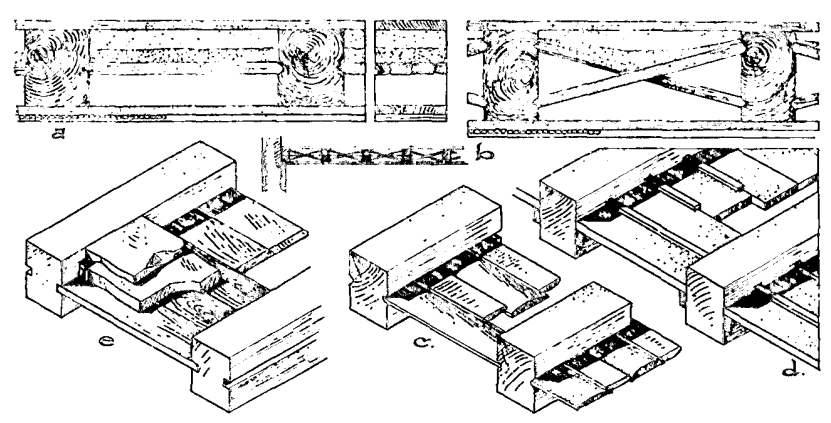

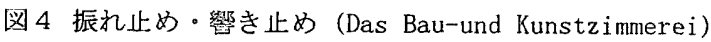



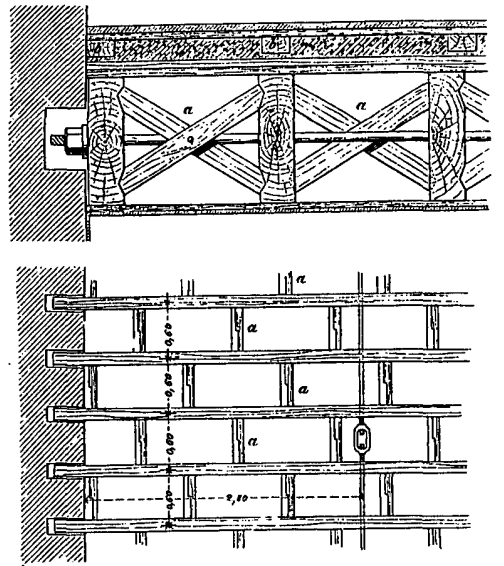

図 5 振れ止め・響き止め (Die Konstruktionen in Holz)

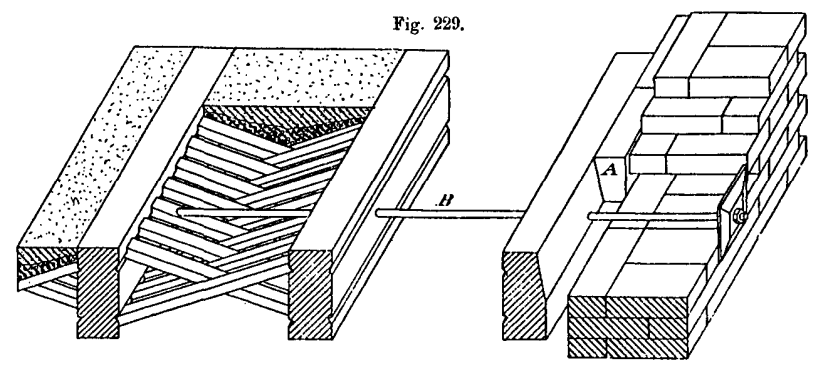

図6 振れ止め・響き止め (Der Zimmermann)

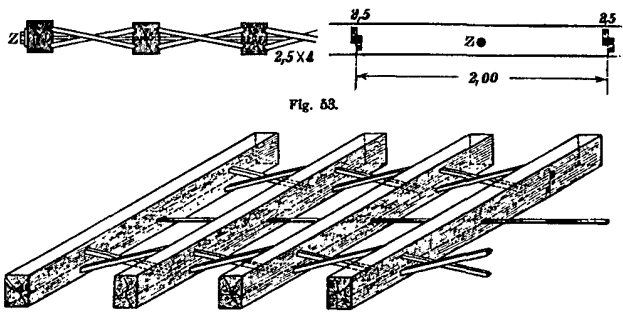

図 7 振れ止め(Die Holzkonstruktionen)

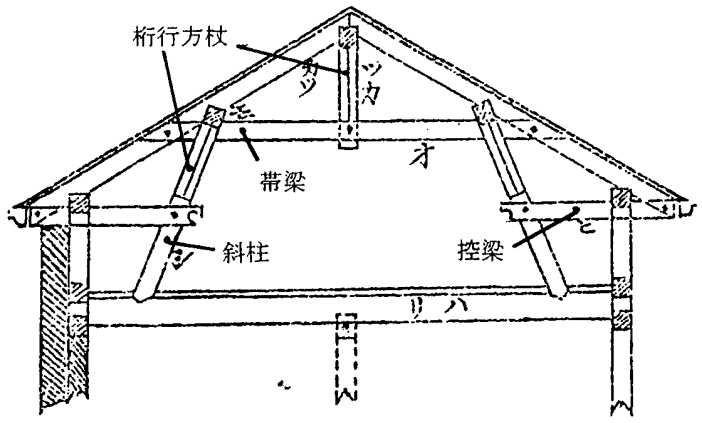

図 8 ドイツ小屋（張間 30 尺以内）（『建築学講義録』）

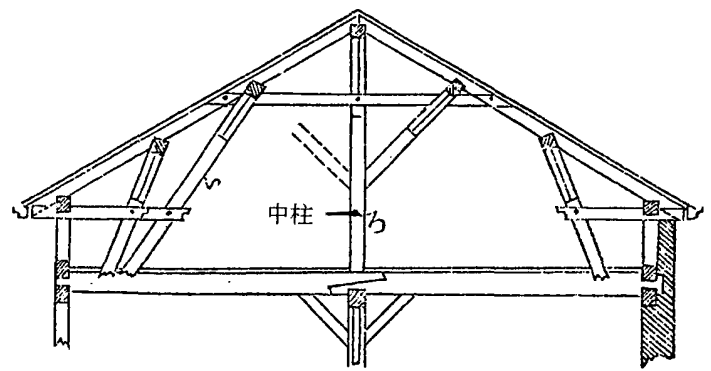

図 9 同（張間 30 尺以上）（『建築学講義録』）
II . ドイツ小屋について

\section{(i ) 明治期の文献}

明治期の文献でドイツ小屋が紹介されていたのは、滝大吉著『建 築学講義録』であった。同書では、ドイツ小屋は小屋裏を用いるた めのものとされ、張間 30 尺以内と、30尺以上の場合に分けて記 述されている14)。その要旨は;

a) 張間 30 尺以内のとき (図 8)

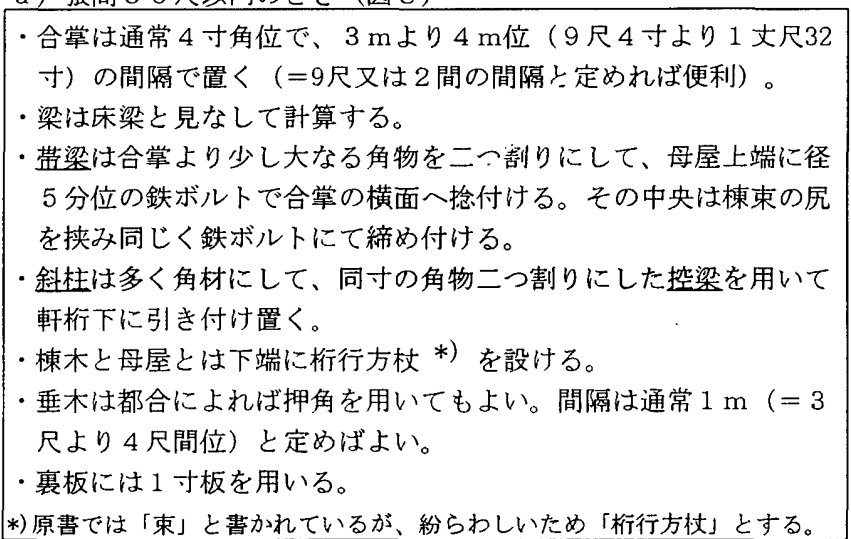

なお、部材名に帯梁（おびばり）、斜柱（しゃちゅう）、控梁 （ひかえばり）という聞きなれない言葉（下線）が用いられている が、本稿では部位を判別できればよいので、一部を除きこのまま用 いることにする。（参照：図 8)

b) 張間 3 ○尺以上のとき (図 9)

・図左の組方は中柱を立てないとき、右は柱を立てるときのもの。 ・床上端より桁迄の高さを $5 、 6$ 尺位にするときは、ほとんど 2 階 建ての家同様となる。

・張間の長く、屋根が高くなりすぎて恰好悪いときは、帯梁より上 を切り取って陸屋根として、その軒先を突出させてこれに木製の 軒蛇腹を設ければ都合よい。

次に、三橋四郎著『和洋改良大建築学』に同様の記述がある15) (図 10 ) 。 その要旨は

・小屋組下に間仕切り壁を設け小屋内を室に用いる経済的な方法。 ・垂木は合掌兼用で母屋上に置き、通常 4 寸角位のものを用いる。

帯梁、控梁等で斜柱及び棟束等を挟み、垂木の横面へ径 5 分棒頭 で締付ける。

この種の小屋には多く押角を用いる。

・垂木は 3 尺位として、裏板には1寸板を用いることが多い。

・陸梁は床梁と同一と見なして計算する。

床上端より析迄の高さを $5 、 6$ 尺位にするときは、ほとんど 2 階 建ての家同様となる。

張間の長く、屋根が高くなりすぎて恰好悪いときは、帯梁より上 を切り取って陸屋根として、その軒先を突出させてこれに木製の 軒蛇腹を設ければ都合よい。

- 参照 : Bau und Kunst Zimmerei von Kreuth und Meyer.

このように、滝と三橋が取り上げたのは母屋組屋根で、両者の解 説はよく似ている。三橋はドイツ小屋の参考文献としてドイツ語文 献を上げているが、同書は先の振れ止めに際して参照した文献と同 一である。そこで、同書を頼りにドイツの小屋組を調べてみよう。

\section{（ i i ）ドイツにおける小屋組}

三橋が参照したクラウトとマイヤーの編集になる『大工と細工仕 事』の第 5 章「木造の継手・仕口の応用」に「在来小屋組」の節が あり、計 6 種類の小屋組が紹介されている16)。それは図 10 と同 
じものである

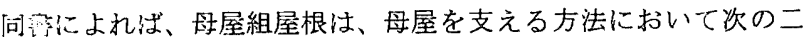
系统に分叮られる。

へ挂屋を直立した「束」で受けるもの。

(2)径屋を傾斜した束、すなわち「斜柱」で受けるもの。

これら二系統の小屋組は、艒母屋が小屋梁の上に直接のるものと、

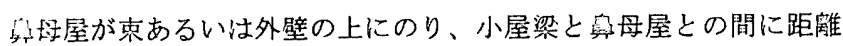
在りくものがある。後者の形式は「半小屋嘎」(Kniestockstuh1) 上訳されている17)。

上記の小屋組の(1)と(2)は、それぞれ半小屋䆆を持つものと持たな いるのに区分されるため、ここまでで小屋組は計 4 種攧となる。

(图10，11，12) このほかに、トラス小屋組、そして小屋

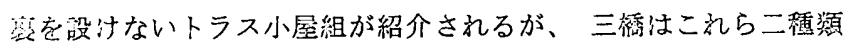
の小屋組については容及していない。

この小屋組の分類に関して別の文献によれば 18)、ドイツにおけ る舫屋組屋根は、まず小屋梁の下にそれを支持する柱あるいは壁体 が有るか無いかで大別される。次に母屋を支持するものが直立した

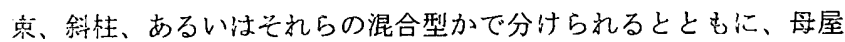
を支持する束の本数（1本から 3 本）によっても区分される。さら

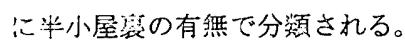

したがって、ドイツに扔ける小屋組からみると、滝と三橎はとも 心小屋梁の下に支持がある母屋組屋根を取り上げているが、滝は、 半小屋政を持ち母屋を斜柱で受けた小屋組を（図 8，9）、三㛢は、

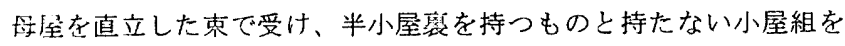
(图10)、それぞれ紹介していたことになる。両者が紹介しよう 上したドイツ小屋は、確かに記述においては酷似していたが、分類 上出別のものだったのである。

III. 法弱省旧本館の埸合

(i) 床組について

汨本館はEの字型の平面をもち、2 階、3 階ともそれぞれ角にあ る部屋と中央䀞をつくる広間は複床であり、その他の諸室は基本的

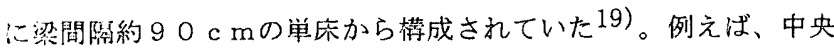
楿の左右に西面して配列された諸室の小梁の寸法は、長 24 尺 6 寸 战 1 尺×幅 7 寸 $(7,455 \times 303 \times 212 \mathrm{~mm})$ であった。

(i i ) 小屋組について

小屋組については、中央槙の賁西方向の断面図、中央槙加ら南北 に伸びる茨廊の断面図と尖塔部分の断面図が存在する。これらの

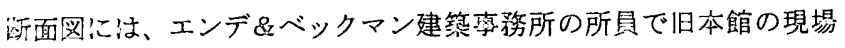
主任を務めたリヒャルト・ゼール（1854～1922）の署名と1892 年 3 月の日付がある。

a) 翟廊の小屋組について（図 13 )

スパン $14,020 \mathrm{~mm}$ 陸梁 $(210 \times 320)$ は、その梁の中央右寄りのと ころで下から搷瓦壁で支えられる。槙木 $(150 \times 200)$ と母屋 $(160$ 210） 沖束 $(160 \times 160)$ で支えられ、これらの束ならびに垂不 $(150 \times 150)$ は、二つ制りの帯梁 $(115 \times 230)$ で結ばれる。空束以 外の束は、方杖 $(180 \times 230)$ によって、また母屋と槙木は胻行方杖 (150－150）によって、それぞれ補強される。

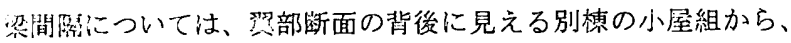
垂不は半間で、陸梁は 2 間半の間隔で配されていたと考えられる。

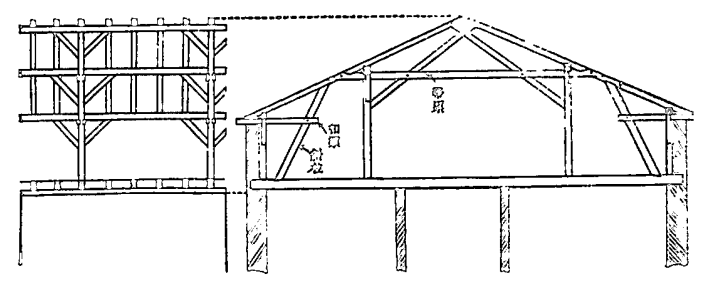

口六十几百四婉

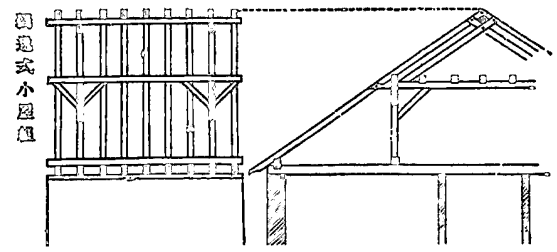

図10 ドイツ小屋（圆の上は半小屋裂を持ち、下は半小屋瓷を持たな い例。母屋忏直立した束で受ける。）（『和洋改良大建築学さ）

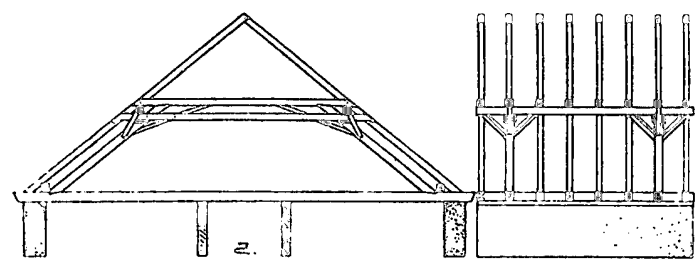

図11 ドイツの小屋組：半小屋皦を持たない例。母屋は斜柱で受ける。 (Das Bau-und Kunstzimmerei)

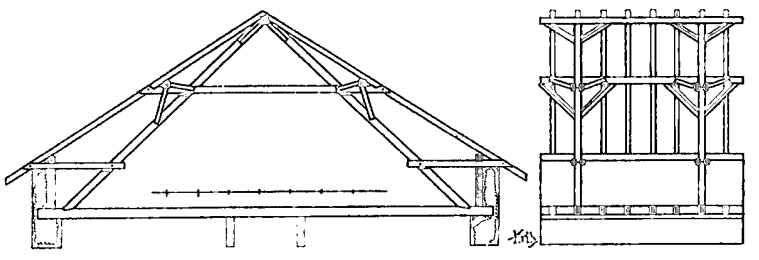

図12 ドイツの小屋組：半小屋㜪を持つ例。母屋は斜杜で受りる。 (Das Bau-und Kunstzimmerei)

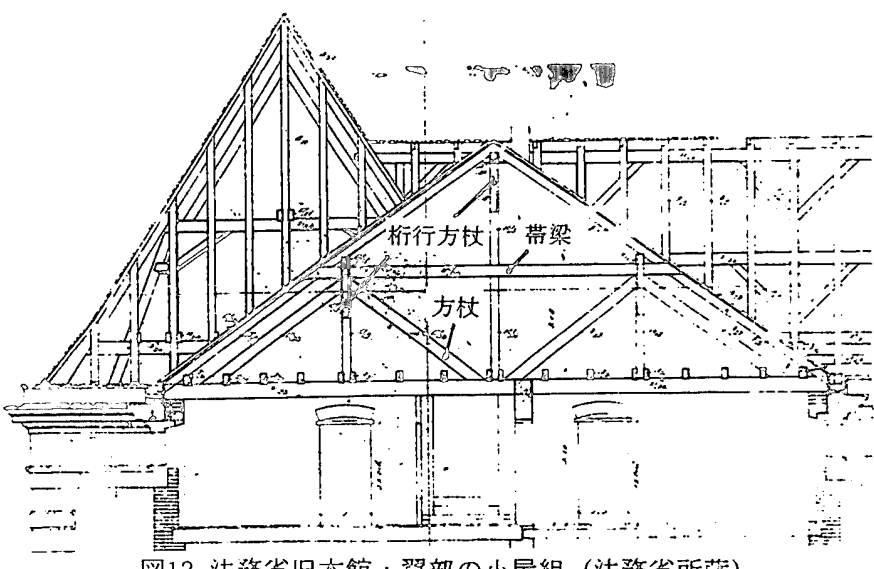

図13 法務省旧本館 : 翼部の小屋組（法務省所藏）

b) 中央梖小屋組について（図 14 )

マンサード屋根の断面を持ち、スパンは両側にあるヴェランダ部 分を含めると約 $2475 \mathrm{~cm}$ で、ヴェランダ部分を除くと約 $1856 \mathrm{~cm}$ である。 小屋燢の高さは、軒高で約 $950 \mathrm{~cm}_{0}$

3 居からなり、第 1 居目の中央やや右寄りに熷瓦壁が立ち上がる。 3 居目にある母屋 $(150 \times 200)$ は寸べて束 $(150 \times 150)$ で支持され、 柬は方杖で補強される。1、2居目の母屋は、斜柱 $(180 \times 210)$ と 帯梁 $(130 \times 300)$ で支えられ、1、2 層の京、斜柱、そして垂不 (150×160) は、この帯梁で結ばれる。2、3層目の母屋は桁行方 
杖（2層目の方杖は $160 \times 160 、 3$ 層目は $130 \times 130 ） て ゙$ 補強される。 また、半小屋裏をもち、鼻母屋 $(160 \times 180)$ は束 $(160 \times 160)$ の上 にのり、その束は斜柱ともども控梁 $(130 \times 230)$ で固定される。

第 1 層と 2 層目の带梁には半間ごとに根太 $(130 \times 250)$ が架かっ ているので、第 1 層目を小屋裏として使用する意図があったことが わかる。

\section{IV. 旧本館の木構造技術の位置づけ}

ドイツの木構造学の文献に紹介された振れ止めは、厚板を使用し ていた。日本では、旧本館に使用された成 1 尺 $\times$ 幅 7 寸の断面をも つ梁のように、ドイツ式は厚板でないところに特徴があると考えら れていた。では、ドイツでは振れ止めは梁には使用されなかったの だろうか。

やや時代を下るが、1911 年に刊行された『木構造ハンドブッ ク』の「床組」には、「重い荷重のかかる倉庫のような建物では、 梁ならびに床板の成を極端に大きくしないために、真々で $60 \sim 8$ O c mというより短い間隔で梁を配置する。厚板による床組におい ては、さらに短い間隔 $(40 \sim 60 \mathrm{~cm})$ で厚板は置かれる。それ は、アメリカで多用されるが、ドイツではあまり用いられない。」 20）十字に組まれた振れ止めによる「補強は、ベルリンで以前はそ こここで応用された。それは、厚板の梁を支えるためではなく、十 分な幅のある梁を、6 m以上の長さで支えられるようにするためで ある。」21)

その図解（図 15 ) には、内法幅 $6.8 \mathrm{~m}$ の部屋に、梁が 80 $90 \mathrm{~cm}$ の間隔で配され、隣り合う梁には約 $2.3 \mathrm{~m}$ の間を置いて 振れ止めが設けられている。

とくに1880年頃から 1930 年頃のドイツでは、梁間隔 90 $\mathrm{cm}$ で、梁の成に対する幅の割合が $5 ： 7$ あるいは $4: 7$ のものが 用いられたという22)。また、梁の長さに対する小口断面の大きさ については、例えば長さ $7 \mathrm{~m}$ の梁の場合は、成 $33 \mathrm{~cm} \times$ 幅 $24 \mathrm{c}$ $\mathrm{m}$ を必要とした ${ }^{23}$ ）。旧本館の小梁の寸法（成 1 尺×幅 7 寸）をド イツの部材と比較してみると、梁の成と幅の割合はドイツ型とほぼ 同一であるが、小口は一回り小さいと言える。旧本館は、この小口 断面の足りなさを振れ止めで補強したことになる。

振れ止めの配置間隔については、日本語文献では、7尺（『建築

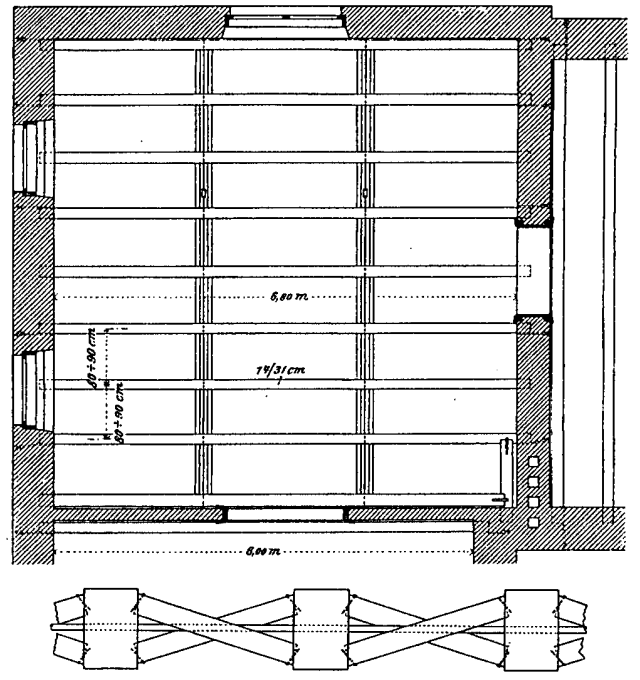

図15 振れ止めの構法例 (Handbuch der Holzkonstruktionen des Zimmermanns)

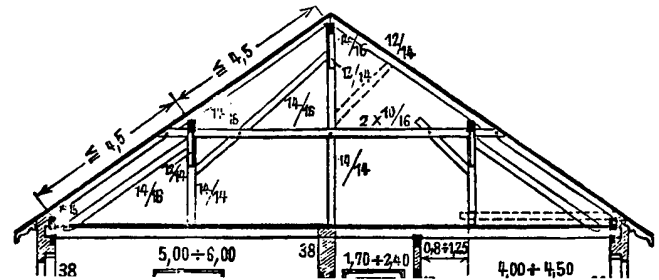

図16ドイツの小屋組：半小屋裏を持たない例。母屋淔立した束で 受ける。(Die Holzkonstruktionen)

学講義録』)、4 あるいは 5 尺（『和洋改良大建築学』）、ドイツ. 語文献では $2 \mathrm{~m} 、 2.3 \mathrm{~m}$ と様々であるが、図 15 の床組例は、旧 本館の仕様に近い。

なお、響き止めについては、旧本館の建築仕様書に「野床」を張 った上で石炭款を充填していることから、本文中の中村と滝が図示 した図 1 と図 2、そしてドイツの構法例では図 5 がそれに該当する。 旧本館の翼部の小屋組は半小屋裏を持たず、 3 本の直立した束が 母屋を支えるというものであり、ドイツにおいて容易に類例を見出 すことが出来る（図16）。

他方、中央棟の小屋組はマンサード屋根で、翼部の切妻屋根とは 異なるが、形式的には母屋組であり、半小屋裹を持ち、母屋を直立

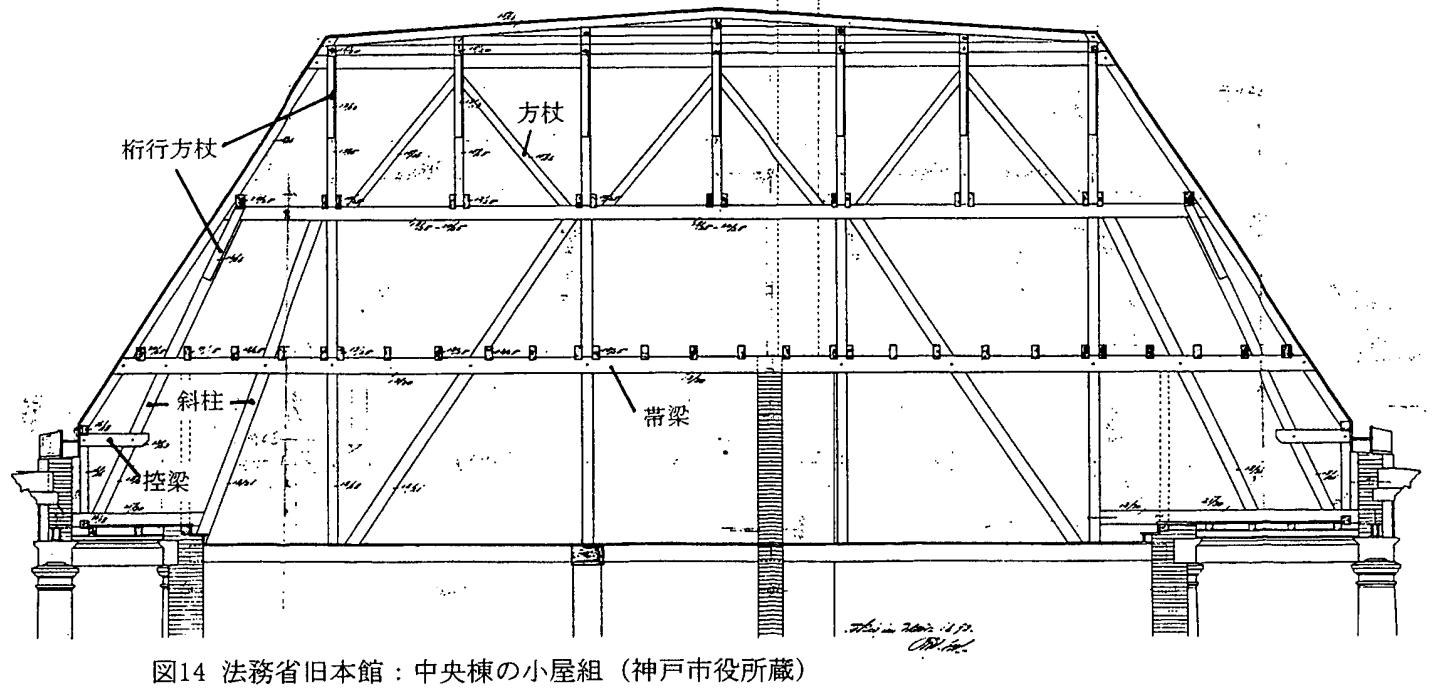


した束と斜柱が支持する混成型である。

上ころで、1891 年10月28日に泿尾地觧が起こり、そのと き司法省建學工程は既に 3 階宏上に達し居りしも何等損害なかり

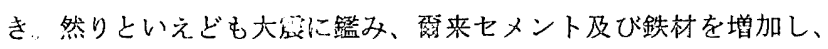

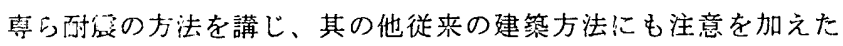
り。」24)とされる。旧本館の小屋組の图面は1892 年 3 月の時 点のものであり、地役後の作成になる。

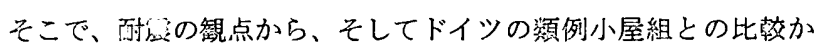
ら、再度旧本館の小屋組を検討してみよう。

まず、翏部の小屋組については、帯梁の下にある束仙左右からそ れぞれ方杖で支えられているので、小屋部の使い勝手を妨げること になる、この点こそがドイツの頑例にないものである(図 16)。 琴部にお汁る左右の方杖の存在流、小屋薪を使う予定のないことを 意味寸るとともに、酎烄への補強であったと考えられる。

次心、中央桹の小屋組については、3 居目の方杖の用い方は嫼部 のそれと同じであり、ドイツに穎例を見出せない。やや時代は先行 寸るが、ドレスデン地方裁判所（1876１879，図17)の小屋組は、 陸梁の長さ約 $22.5 \mathrm{~m}$ のマンサード屋根であるが、斜柱の本数は 旧本館の半分厄゙りり、带梁は並立するすべての束を挟むわけではな く、小屋䅇は待るかに広々としている。

さらに、日独で使用された部材寸法を比㪟してみると、例えば旧 本館の糸部小屋組の部材はドイツのものよりも大きかった（表 1)。 表1 部材寸法の比較25）

\begin{tabular}{|c|c|c|}
\hline 韵材名 & 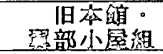 & ドイツの烦列 \\
\hline 洗 梁 (锭) & $14.0 \mathrm{~m}$ & $12.4 \sim 14.7 \mathrm{~m}$ \\
\hline [问－（福次成） & $210 \times 320$ 밈 & $180 \times 240 \mathrm{og}$ \\
\hline 亘 束 & $160 \times 160$ & $140 \times 140$ \\
\hline 满梁（合せ濯） & $115 \times 230$ & $100 \times 160$ \\
\hline 斜 柱 & $180 \times 230$ & $140 \times 160$ \\
\hline 方 & $150 \times 150$ & $120 \times 140$ \\
\hline 舴 屋 & $160 \times 210$ & $140 \times 160$ \\
\hline 垂 不 & $150 \times 150$ & $120 \times 140$ \\
\hline
\end{tabular}

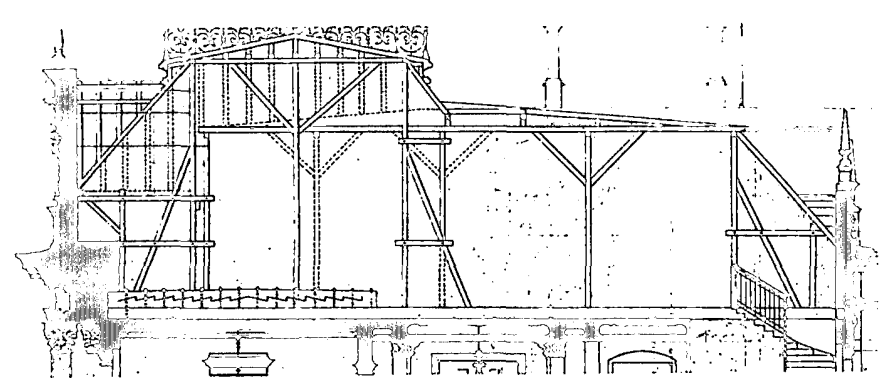

図17ドイツの小屋組：マンサード屋根のドレスデン地方裁判所 (1876 1879) (Zeitschrift für Bawwesen, 1882)

缩 踰

法剓省旧本館の復原考察を通じて、不模造技術については次のよ うこ要約できる。

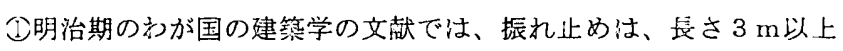

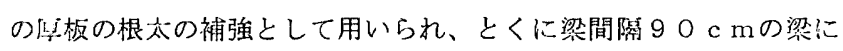
用いるのがドイツ式と䓅えられていた。

(2)ドイツで出、振れ止めは、梁間開 40 O $60 \mathrm{~cm}$ で長さ $6 \mathrm{~m}$ 以上 の席桢の根太の補強として用いられたが、とくにベルリンに扔いて

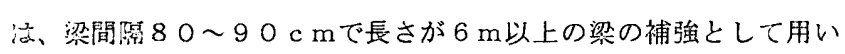
られた。
(3)旧本館の床組は基本的に梁間隔 $90 \mathrm{~cm}$ 岸床からなり、根太に は厚板ではなく、梁を用いていたこと、その補強として振れ止めが

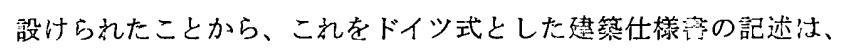
創建当時の日独（とくにベルリン）のこの種の草法と一致していた。

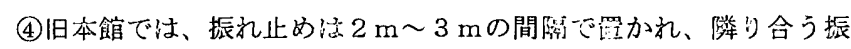
れ止めの間もしくは梁の上に板がはめられ、その上にモルタルある

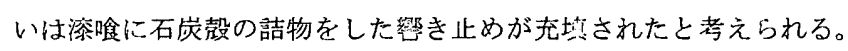
(5)明治期のわが国に紹介されたドイツ小屋は、半小屋贸を持ち母屋 を斜柱で受けたもの、母屋を直立した束で受け、半小屋望を持つも のと持たない小屋組のタイプであった。

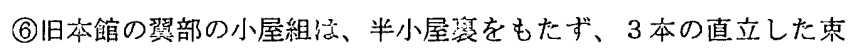
が母屋を支持していたのに対して、中央槙のそれは、マンサード屋 根の母屋組で、半小屋新をもち、母屋を直立した束と斜柱が支持寸 る混成型であった。

(7)旧本館の小屋組は、とくに斜柱がドイツよりも多く挿入され、部 材寸法はドイツのものよりもはるかに大きかった。これは、小屋站

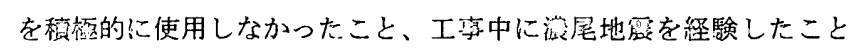
で、耐放計が強化されたことによると考えられる。

注

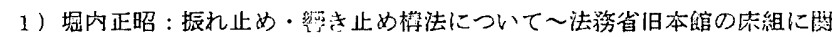

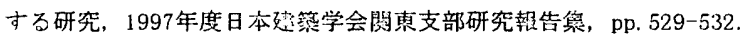

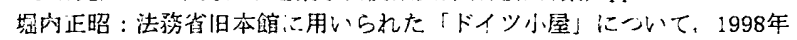

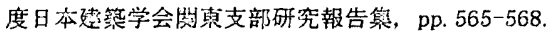

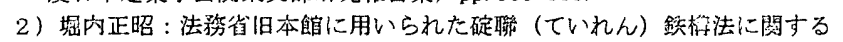

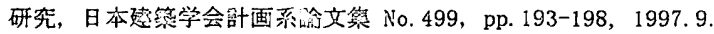

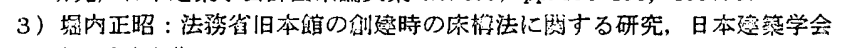
湖面系渝立等 No. 518 , pp. 277-282, 1999. 4.

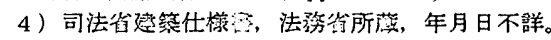

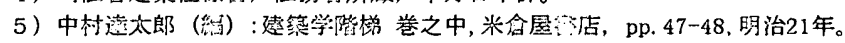

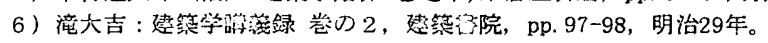

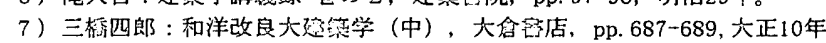
(第13版, 初版明治 37 年)

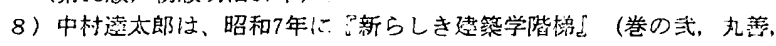

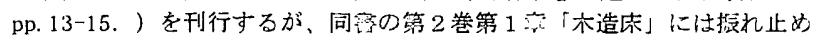

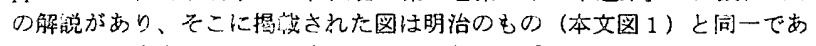

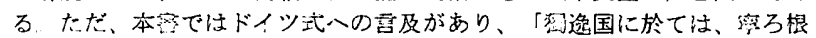
太と称するよりは梁と称することが普通である程の大なる根太を、1洸ま 程に『きて単㡷とすることが曾通である」と追硙されている。

9) Krauth, T. , Yeyer, F. S. (eds. ), Die Bau-und Kunstzimmerei, Leipzig, 1895 (管2版, 初版1893, Reprint, 1994, pp. 129-130.)

10) Warth, O. Die Konstruktionen in Holz, in : Allgemeine Baukonst rukt ionslehre. Band 2, Leipzi g, 1900 (第6版. Reprint, 1994, p. 74.)

11) Issel, Hans (ed.), Das Handbuch des Bautechnikers 1. Band, Baukonstruktionslehre 1. Teil Der Zimmermann, Leipzig, 1902 (第2版). p. 64.

12) Stade, Franz (ed.) , Die Schule des Bautechnikers Band:Holzkonst rukt ionen, Leipzig, 1904 (Reprint, 1997, p. 43.)

13) Ahnert, R. , Krause, K. H. : Typi sche Baukonstruktionen von 1860 bis 1960, Berlin, 1991, p. 121.

14）漠六吉 : 前揭, pp. 214-218.

15) 三奞四郎 : 前揭, pp. 521-524.

16) Krauth, T., 海eyer, F. S. (eds. ), op. cit., pp. 130-152

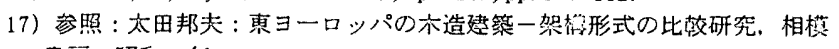
灵落，昭和63年。

18) St ade. Franz (ed. ), op. cit. , pp. 157-167.

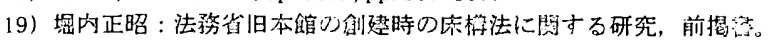

20) 21) Boehm, Theodor, Handbuch der Holzkonstruktionen des Zimmermanns. Berl in. 1911, pp. 123-125.

22) Ahnert, R. , Krause, K. H. : op. cit., p. 100.

23) Ibid., p. 132.

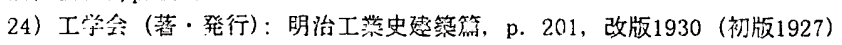

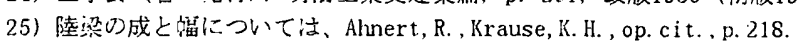

